\title{
EFL Teachers' Perception and Strategies for Integrating Character Education into the Lesson
}

\author{
Ni P.J.E. Putri' ${ }^{1, *}$, L.P. Artini², L.G.E. Wahyuni ${ }^{3}$ \\ ${ }^{1}$ English Language Education, Universitas Pendidikan Ganesha, Jalan Udayana 11, Singaraja, Bali, Indonesia \\ *Corresponding author: juliaekaputri5@gmail.com
}

\begin{abstract}
The recent phenomena of moral degradation of Indonesian youth are responded by policy in moral and character education. Character education in schools is included in the curriculum and it must be integrated into the subjects matter. This study aims at investigating how English teachers perceive character education in the context of teaching English as well as the strategies in inserting character education into the lesson by conducting explanatory sequential mixed method design. The participants of this study were seventh and eighth grade English teachers in SMPN 6 Singaraja. The data were collected by means of questionnaire, observation sheet, and interview guide. As the result, this study revealed that English teachers had sufficient knowledge of Character Education concept. The way they implemented the character education did not really represent how character education should be inserted. Furthermore, they also were not sure of its impact to the students' character development. It indicates that they had lack understanding of character education and the implementation of character education. The way English teachers integrate character education into further learning is discussed in a research discussion. Furthermore, enriching their knowledge of the character education should be the first step done.
\end{abstract}

Keywords: character education; perception; English teacher

\section{Introduction}

According to Indonesian National Education System, the goal of national education is to develop educated people with good life skills and good character building. Character is the combination of qualities which includes the nature, qualities, achievement also abilities of a person (Adi,2013). Furthermore, Tsai and Agboola (2012) state that character can be defined as a measurement of manners. These manners are influenced by inside and outside behaviour. Pike (2010) stresses that when someone has a good character, she or he also has good trustworthiness, integrity, and passion. It can be said that character education is important in developing many aspects such as academic achievement and behaviour.

In terms of academic achievement, experts stated that character education has a strong connection with academic achievement. According to Adams (2013) children when educated with character education feel valued, safe and motivated. Those are important aspects of acquiring higher academic achievement. Baker (2013) supports that character education at school is often touted as a way to help students become better citizens. But teaching kids skills and values like respect, honesty and persistence improves their academic success as well. 
Furthermore, the need for character education lies in the moral degradation found in society. Berkowitz and Bier (2005) state that character education can help people especially young generation build good character that in turn can help to build good societies, likewise the effective character education can have many different outcomes. The one that clearly takes attention is that character education frequently improves academic performance, reduces risk behaviours such as drug use, violence, pre-marital sexual behaviour and it can increase desirable behaviours such as being care with environment, helping students to interact properly with their teachers and fellow students, and turning their classroom into a better learning environment. It is supported by Goss and Holt (2014) that the implementation of character education can increase socio-moral cognitive development, problem solving skills, emotional competency, improve academic achievement and it decreases students' negative behaviours. Besides that, when students are educated with character values, they will be able distinguishing appropriate action from inappropriate one.

However, there is a big challenge occurs recently in achieving the goal of good character building as degradation of moral among students in Indonesia. Bhakta (2017)and Sihombing (2014) state that the exposure to digital world can somehow affect the degradation. Cozma (2011) states that globalization does not only brings positive impact but also negative impact to careless young generation. Globalization has become so present in the midst of families: teaching users anything at any time, changing lifestyle, bringing new habits. Globalization is a form of sophisticated hypnosis people who are able to change behaviours and the way they communicate with the others (Istiyanto, 2016). Muthohar (2013) argues that the concept of politeness morality becomes loose because it is influenced by western culture and the ease of finding information in this globalization era. Besides the explanation above, moral degradation is also influenced by other things as expressed by Bhakta (2017), moral degradation or character of person can also be affected by school environment, family and society because young generation has a wide environment in interacting or socializing with others.

Regarding the moral degradation, Hidayati et al. (2014) state that there are variations of students' negative behaviour that appear in school like cheating during the test, fighting, consuming drugs, alcohol and promiscuity. In addition, Hartini (2017) also mentions some related problems which usually happen such as talking inappropriately or using rude speech, disobeying law in school, being truant, being indiscipline, being involved in motorcycle gang, smoking, consuming alcohol, quarrelling, doing adultery and demonstrating bad 
manner in interacting with the others. Similar phenomenon also happened in SMP Negeri 6 Singaraja, when a needed preliminary observation was conducted students still showed negative behaviours in front of teachers, such as being disrespectful, being truant, opposing the teacher, saying rude words, breaking the rules and making noise, ignoring assignments given, cheating, bullying, annoying their friends, refusing to pray, etc.

In responding to moral degradation, Curriculum 2013 is integrated to the implementation of character education within the schools in Indonesia. Likewise with SMP Negeri 6 Singaraja, the school has already implemented the curriculum 2013 which emphasizes character education in teaching and learning process. The evidence of its implementation in SMP Negeri 6 Singaraja can be seen from the activities carried out. Two of them are the students should pray together in the class based on their beliefs and sing National anthem before the learning process begins.

Character education must be prioritized in secondary school because junior high school students are students who are around 12 to 16 years old, who are entering the transition of a change in childhood to early adolescence, which usually they want to show their identity by behaving imitating their idols and also they are still unstable (Suradi, 2017). In line with this, Muthohar (2013) states that teenagers are the generation who are mostly vulnerable to negative influences, although they have the potential to be directed towards positive things but so hard to achieve that. Therefore, junior high school students still need to be taught character education so that they can behave well.

Pertaining to the implementation of Curriculum 2013, Ministry Education and Culture (2014) states that Curriculum 2013 has been developed focusing on three divisions: attitude, knowledge, and skill. In comparison to the previous curriculum, Curriculum 2013 has differences, in which it gives a clearer indication of how the character values are to be planned, implemented, and assessed (Indrayani, Artini, \& Seken, 2018). Furthermore, Rahmi and Erlinda (2014) state that Curriculum 2013 demands the teacher to focus not only on cognitive evaluation in doing learning activity, but also character evaluation in every subject. They also state that Curriculum 2013 aims at increasing curiosity and activeness of students and one of the important goals is implementing character values. According to Ministry Education and Culture (2014), there are 18 core values to be incorporated in instructional process in Indonesia.

However, those 18 main values of character education have been updated. Based on Muttaqin, Raharjo, and Masturi (2018) the implementation of character education value through the intellectual education is always adjusted to emphasizing character education 
through the character education reinforcement. The character education reinforcement has five values of priority in the national character (Muttaqin et al., 2018) namely: (1) Religious; (2) Nationalist; (3) Independent; (4) Collaboration; and (5) Integrity. These five values of priority are connected from one to another. The Presidential Regulation Article 18 No. 87 Year 2017 explains that the implementation of character education reinforcement in the formal degree of educational unit should be performed under integrated manner through the intra-curricular, co-curricular, and extra- curricular activities. It means that each school should have a character education reinforcement implementation plan.

To support the character education reinforcement program, the role of the teacher is very crucial. As people who interact more with students, teachers must insert the values of character education reinforcement. Rahmi and Erlinda (2014) state that teachers' role in the classroom is not only about delivering knowledge through the material provided by the school, but teacher might be able to implement character education through appropriate teaching and learning approach. Harmer (2007) also states that the way teacher acts in classroom plays a crucial point in building students' character. It can be said that, teachers are the key role in developing students' cognitive skill and as example for the students.

A primary observation was conducted in SMP Negeri 6 Singaraja. Students showed sign of negative behaviors, such as being disrespectful, being truant, opposing the teacher, saying rude, breaking the rules, making noise when the teacher explained the material, ignoring assignments given, cheating, and bullying. This indicates that the character education is not well implemented. Although it is not only teachers obligation to apply the values of character education, as parents role should be considered as well, it is very important to identify how the teacher views and applies those values in the classroom. Based on the explanation, this study attempts to investigate English teachers' perceptions and strategies for inserting characters education into the lesson at SMP Negeri 6 Singaraja.

\section{Materials and Methods}

This is an explanatory sequential mixed method study conducted at SMP Negeri 6 Singaraja. The subjects included in this research were English teachers of grade 7 and 8 who were 4 teachers altogether. The object of this study was English teachers' perception and strategies for inserting character education into the lesson. The data were collected through questionnaire, observation and deep interview for each teacher. 
A structured observation was conducted involving more than 3 times observations in each. A video recorder was used to record the whole teaching and learning processes to know the English teachers strategies in inserting character education into their lesson. During the observation, observations sheets were also used to write down what strategies were used by the teachers in inserting that character education. In addition, semi structured interviews were done formally with a list of questions to the participants but some spontaneous questions was arisen during the interview to acquire deep information

The data were analysed quantitatively and qualitatively. Quantitatively means that the result of questionnaire was analysed by using SPSS. While qualitatively means that the result of the observation and interview were analysed by using interactive process which consists of four components such as, data collection, data reduction, data display and conclusion or verifying

\section{Results and Discussion}

The perceptions of English teachers on the concept of character education was measured using questionnaire that consists of 31 items of statements covering the dimension of the concept of character education which encompasses of 10 items, the dimension of the implementation of character education consists of 12 items of statements and so does the dimension of the impact of character education which consists of 9 items of statements. The finding based on the dimensions, as the result of the English teachers' perception on character education is shown in Table 1.

Table 1. Descriptive Statistic Analysis on the Concept of Character Education

\begin{tabular}{llllll}
\hline Dimension & $\mathrm{N}$ & Minimum & Maximum & Mean & Categorization \\
\hline $\begin{array}{l}\text { Concept of Character } \\
\text { Education }\end{array}$ & 4.10 & 4.70 & 4.450 & Average \\
$\begin{array}{l}\text { Implementation of } \\
\text { Character Education }\end{array}$ & 4 & 4.08 & 4.50 & 4.250 & Low \\
$\begin{array}{l}\text { Impact of Character } 4 \\
\text { Education }\end{array}$ & 3.67 & 3.67 & 4.111 & Average \\
\hline
\end{tabular}

On the concept dimension, teacher knowledge about character education is still categorized as average $(M=4.45)$. This means that there are still many teachers who do not understand the concept of character education. The results of the interview also found that teachers have limited knowledge about the concept of character education as well as limited knowledge about values in character education. They only know some of them such as 
cooperation and self-directedness. It showed that the participants of this study had lack understanding toward the concept of character education.

The teacher realize that it is important to apply character education. The majority of the participant agreed that character education is important for overcoming the moral crisis that is sweeping the nation. In the interview, English teachers stated character education is important since it is able to reduce students' negative attitudes or behaviours, students become more polite and respectful towards teachers or other school members. Character education, can also make students better in the future, they would be able to be a leaders for others, because in this modern era, character is the most important and highly seen by others.However the result of questionnaire in terms of implementation of character education was low $(M=4.50)$. This indicates that the teachers are not able to implement character education in classroom despite of their understanding on the importance of it. The result of interview, revealed that the teachers have tried to find effective methods so that the values of character education can be conveyed to students but it is beyond teachers' expectation.

Most important thing that the teacher realize the importance of their role integrating character education in teaching and learning process. Indrayani et al. (2018) state that in introducing character education, it is not only a main obligation of families, but is rather effectively developed through schooling. According toHasanah et al. (2017), the development of person character is affected by environment, including school environment, family and society. As supported by Berkowitz and Hoppe (2009), students' character can be developed through character education, because character education is a deliberate effort used to promote character education in school by the teachers.

This is an indication that teacher have a huge role in teaching character education. Adults, particularly teachers are expected to be role models reflecting positive values within and beyond classroom activities (Yildirim, 2009).As explain by Harmer (2004), a good teacher is the on who has good personality and does not hide it from the students. It means that teachers in the classroom has a position not to be only a someone who teach students the subject matter but the way she or he acts in from of the students play crucial point in building students character. In the context of language learning, the responsibility of teacher in the classroom is not only about teaching the linguistic structure of language but more than that the teacher has main part as character educator, teachers should integrated character education (Rahmi \& Erlinda, 2014). 
On the impact of character education, teachers have average perception $(M=3.67)$. The majority of English teachers agreed that character education has a positive impact on students' academic success. The majority of English teachers perceived that character education can supports learning activities and also have positive effect toward students' behavior and academic success. Teachers agreed that character education can reverse the moral deterioration felt by society in this era and majority of the English teachers. They also agreed that student negative behaviour can be reduced through character education. The result of interview revealed that teacher believed that character education brings many positive influences to the students themselves, teachers, schools, communities and even our nation.

The importance of integrating character education has been recognized by several studies. Wahyutiningsih (2016) states that moral education or character education should be strengthened in order to overcome moral crisis. Character education is important to integrated in classroom because it can help teachers in assessing students' character and encourage the students for improvement(Sakti, 2017). Fallis et al. (2013) identified that the outcome of character education has always encouraged and prepared character of children in order to make their character become better, and then by character education it can build a good leader in the future. Hoge (2002) also supports that character education can be a way of adapting the students' behaviour in order to prepare good generation of the future. In line with that,Rahmi and Erlinda (2014), regarding the aim of character education, there are three important points why character building through character education is needed in our country, one of them is character education can improve the civilization of a nation that can compete in the world association.

On the behave of learning, Goss and Holt (2014)state that the implementation of character education can increase socio-moral cognitive development, problem solving skills, emotional competency, improve academic achievement and it decreases in negative student behaviours.Trisiana (2006) supported this finding, in which she state that character education is able to develop the students' potentials to become a faithful, noble, healthy, knowledgeable, capable, creative, independent individuals, and to become democratic and responsible citizen. According to Artini (2019), every country in the world has put much attention toward how characters should be taught to the young generation so that they become responsible citizen and positively contribute to their community, promote a good way of living, and respectful to others. Alexander (2016), his study revealed that character development is important for students in school and beyond. Since the teachers in this study 
believed that in the long term character education can affect the academic outcomes of students. As also stated by Fallis et al. (2013), a number of researches found the positive results of implemented character education programs in the schools, including higher academic achievements, fewer suspensions as well as dropout, and fewer risk behaviours of students.

During the observations, teachers did some strategies in inserting character education. In integrating religious value, the teachers invited the students to pray before and after teaching learning process, remind students who do not pray, provide equal opportunities for students to pray based on their respective religions and beliefs. Besides that, the teacher give reminder to the students to always keep their words so as not to offend others, remind students not to speak rude or dirty, give examples of how to behave. In teaching tolerance value, the teachers asked the students to speak and act in a good way, remind students not to commit criminal and violence acts, provide the same treatment to all students without distinguishing ethnicity, religion, race, class, social status, and economic status.

In teaching nationalist value, the teacher asked the students to use good and correct Bahasa Indonesia, respects the leader of the country, and remind students to obey the applicable regulations. Besides that, the flag ceremony was indication that the teacher and school are already teaching nationalist value. Teachers also used some strategies in inserting self-directedness value, those are create good competition, create a work ethic, never giving up, and endurance in learning, creating a learning atmosphere that promotes work durability, motivate students to work hard and learn, create tasks that increase student independence, create learning that can foster critical thinking and creative action.

It is indeed that there are many ways of integrating character value in the process of teaching and learning. The study conducted by Nova (2017) revealed that the teachers have inserted character education into their lesson with various frequencies and also have inserted character values with different focuses. Most of them inserted character education with different ways, those are explicit and implicit modes. In line with the study by Ratih (2017), she found that some of the values were inserted explicitly, some others values were implicitly inherent in activities. Hutami (2013) states that it is really important to relate learning materials to a real life and motivate the students to make connections between the knowledge they learned and their own lives. It is believed that it brings positive effects into students' academic achievement and their behaviour. 
From the explanation above, it can be stated that despite teachers' understanding on the concept, importance and implementation of character education, teachers still find difficulties in building students' character. The teachers had done many strategies in order to insert character education in the learning process. The process may take years since students who showed a negative behaviour are still remained. However, the most important thing for the teacher is that they become a good model for their students. Before teaching character value to the students, the teachers should have and show the character to the students.

\section{Conclusion}

The present study intended to investigate English teachers' perception toward character education, English teachers' strategies in inserting character education through questionnaire, observation and interview.

Based on the result of this study, it can be concluded that English teachers in SMP Negeri 6 Singaraja English teachers had sufficient knowledge of Character Education concept. The way they implemented the character education did not really represent how character education should be inserted. Furthermore, they also were not sure of its impact to the students' character development. It indicates that they had lack understanding of how to incorporate and evaluate character education in their lessons.

However, their strategies in inserting character education were in good category. It can be seen that English teachers used many strategies in inserting character values. They have implement more strategies other than what they have mention during the interview. It can be said that they were inserting character education unconsciously. Although there were some teachers who insert character education explicitly and some insert it implicitly, overall character education values have been inserted into the lesson during their teaching and learning process.

Since the English teachers' perception of character education was perceived to be in average and low category, English teachers should look for information related to character education through their own personal learning. Besides, personal learning school administrator may provide room for teachers to discuss strategies for incorporating character values in their lesson. It should be more understood by the teachers to enrich their knowledge about character education. Due the limitation of the sample size of the study, further investigation is needed. It might be involving teachers teaching across grades or teachers with different school contexts. Moreover, research in area of character education reinforcement is 
limited. Additional factors affecting character education need to be explored. This study could provide reference for further exploration of character education.

\section{References}

Adam, C. (2013). How Character Education Can Improve Student Achievement. Accessed December $15^{\text {th }} 2019$ From https://www.howtolearn.com/2013/03/how-charactereducation-can-improve-student-achievement/

Adi, S. S. (2013). Character building in language learning: Immersion principle in the implementation of responsible, fair, and care values in developing EFL classroom activities. The 5th National English Language Teachers and Lecturers (NELTAL) Conference, 0-9.

Alexander, A. A. (2016). Teacher perceptions of the effectiveness of character building initiatives at an expeditionary learning outward bound high school. City University of New York (CUNY).

Artini, L. P. (2019). Character education practice in primary school in Bali, 178(ICoIE 2018), $535-540$.

Baker, C. (2013). Character education boosts academic achievement. Accessed December 22th from https://www.deseret.com/2013/3/10/20515795/character-education-boostsacademic-achievement

Berkowitz, M. W., \& Bier, M. C. (2005). What works in character education: A report for policy makers and opinion leaders. University of Missouri- St Louis, Washington. Retrieved from http://www.character.org/uploads/PDFs/White_Papers/White_Paper_What_Works_Poli cy.pdf

Berkowitz, M. W., \& Hoppe, M. A. (2009). Character education and gifted children. High Ability Studies, 20(2), 131-142. https://doi.org/10.1080/13598130903358493

Bhakta, D. K. (2017). Degradation of moral values among young generation : A contempory Issue in India. International Research Journal of Interdisciplinary \& Multidisciplinary Studies (IRJIMS), 7969(128), 128-133.

Cozma, I. (2011). The relation between globalization and personal values across 53 countries and 28 years. trace.Tennessee.Edu, 131. Retrieved from http://trace.tennessee.edu/cgi/viewcontent.cgi?article=2093\&context=utk_graddiss

Fallis, A. ., Madkur, A., Narvaez, D., Lapsley, D., Silvia, A., Steedly, M. M., ... Larson, K. (2013). Understanding the importance of character education. The Asian Conference on Language Learning, 3(4), 1-16.https://doi.org/10.1017/CBO9781107415324.004

Goss, S. J., \& Holt, C. R. (2014). Perceived impact of character education program at a midwest rural middle school: A case study. University of Arkansas.

Harmer, J. (2007). How to teach English (6th ed.). England: Pearson Education.

Hartini, S. (2017). Pendidikan karakter disiplin siswa di era modern sinergi orang tua dan guru MTs Negeri Kabupaten Klaten. Journal Basic Of Education,2(1), 38-59.

Hasanah, N., \& Tua, P. O. (2017). Peran orang tua dalam pendidikan karakter anak usia dini 
melalui ranah afektif. In Prosiding Seminar Nasional Tahunan Fakultas Ilmu Sosial Universitas Negeri Medan (Vol. 1, pp. 371-374).

Hidayati, A., Zaim, M., Rukun, K., \& Darmansyah. (2014). The development of character education curriculum for elementary student in West Sumatra. International Journal of Education and Research, 2(6), 189-198.

Hutami, M. P. (2013). Portraying the integration of character education in teaching English as a foreign language to grade XI students of SMA Negeri 4 Yogyakarta in the academic year of 2011-2012: A case study.

Indrayani, L., Artini, L. P., \& Seken, K. (2018). Character education practices at a piloted primary school. In 1st International Conference on Education Innovation (ICEI 2017) (Vol. 173, pp. 4-7).

Istiyanto, S. B. (2016). Telepon genggam dan perubahan sosial: Studi kasus dampak negatif media komunikasi dan informasi bagi anak-anak di Kelurahan Bobosan Puwokerto Kabupaten Banyumas. Jurnal Komunikasi, 1, 58-63.

Ministry, E. C. (2014). Konsep dan implementasi kurikulum 2013. Jakarta: Ministry of Education and Culture.

Muthohar, S. (2013). Antisipasi degradasi moral di era global. Jurnal Pendidikan Islam, 7(2), 321-334.

Muttaqin, M. F., Raharjo, T. J., \& Masturi. (2018). The implementation main values of character education reinforcement in elementary school. Journal of Primary Education, 7(1), 103-112.

Nova, M. (2017). Pendidikan karakter di kelas EFL Indonesia: Implementasi dan hambatan. Jurnal Pendidikan Karakter, 7(2), 142-157.

Pike, M. A. (2010). Christianity and character education: Faith in core values? Journal of Beliefs and Values, 31(3), 311-321. https://doi.org/10.1080/13617672.2010.521008

Rahmi, M., \& Erlinda, R. (2014). Teachers' role in building students' character through English language teaching classroom. In Proceeding of the Third International Seminar on Languages and Arts (pp. 320-327). Padang.

Ratih, I. A. . (2017). The analysis of classroom character education in English lessons based on the 2013 curriculum. Journal of Psychology and Instruction, 2(1), 97-105.

Sakti, B. P. (2017). Indikator pengembangan karakter siswa.

Sihombing, S. O. (2014). Identifying current values of Indonesian youth. In The 9th International Conference on Business and Management Research "International Market Integration." Kyoto: Kyoto University.

Suradi. (2017). Pembentukan karakter siswa melalui penerapan disiplin tata tertib sekolah. Jurnal Riset Dan Konseptual, 2(November), 522-533.

Trisiana, A. (2006). An analysis of the implementation of character education policy in school to meet the asean economic community.

Tsai, K. C., \& Agboola, A. (2012). Bring character education into classroom. European Journal of Educational Research, 1 (2), 163-170. https://doi.org/10.12973/eujer.1.2.163

Wahyutiningsih, W. (2016). Character education as the place for shaping the morality of children of the nation. International Conference on Education (IECO), 1 (July), 314- 
323.

Yildirim, K. (2009). Values education experiences of Turkish class teachers: a phenomonological approach. Egitim Arastirmalari-Eurasian Journal of Educational Research, 9(35), 165-184. 